\title{
TNC wt Allele
}

National Cancer Institute

\section{Source}

National Cancer Institute. TNC wt Allele. NCI Thesaurus. Code C52122.

Human TNC wild-type allele is located within 9q32-q34 and is approximately $98 \mathrm{~kb}$ in length. This allele, which encodes tenascin protein, is involved in extracellular matrix conformation. 